\begin{tabular}{|c|c|c|c|}
\hline $\begin{array}{c}\text { A } \\
\text { REVIEW }\end{array}$ & $\begin{array}{r}\text { ADVANCE RESEARCF } \\
\text { volume } 8 \mid \text { Issue } 1 \mid\end{array}$ & $\begin{array}{l}\text { OCIAL SCIENCE } \\
231-6418\end{array}$ & \\
\hline $0=$ & DOI: 10.15740/HAS/ARJSS/8.1/116-136 & Visit us : www.researchjournal.co.in & \\
\hline
\end{tabular}

\title{
A study of parliamentary and Presidential form of Government, recent trends in the Indian system of Government and problems faced by the Indian Judicial System
}

Shriya Singh* and Mukund Sarda ${ }^{1}$

Department of Law, New Law College, Bharati Vidyapeeth (Deemed University), PUNE (M.S.) INDIA

${ }^{1}$ Faculty of Law, New Law College, Bharati Vidyapeeth (Deemed University), PUNE (M.S.) INDIA

\section{ARTICLE INFO :}

Received

: 04.03 .2017

Accepted

28.05.2017

\section{KEY WORDS :}

Parliamentary, Presidential, Indian system of Government, Indian Judicial system

\section{HOW TO CITE THIS ARTICLE :}

Singh, Shriya and Sarda, Mukund (2017).

A study of parliamentary and Presidential form of Government, recent trends in the Indian system of Government and problems faced by the Indian Judicial System. Adv. Res. J. Soc. Sci., 8 (1) : 116136, DOI: 10.15740/HAS/ARJSS/8.1/ 116-136.

*Author for correspondence

\begin{abstract}
The article studies the oldest forms of Government in the world i.e. Parliamentary and Presidential form of Government. The article elaborates various features of both the forms. In addition to this, the article also brings about some light on the recent trends in the Indian system of Governance detailing its various aspects. Throuhout the research various cases have been discussed which elaborates the evolution of judicial system of problems faced by the Indian judiciary in keeping trhe complexity of the largest democracy of the world.
\end{abstract}

